

Jurnal Kedokteran dan Kesehatan Indonesia

Indonesian Journal of Medicine and Health

Journal homepage: https://journal.uii.ac.id/JKKI

\title{
Multidrug-resistant Klebsiella pneumoniae from clinical isolates at dr. Soeradji Tirtonegoro central hospital Klaten
}

\author{
Handi Virawan ${ }^{1}$, Titik Nuryastuti $^{2}$, Hera Nirwati*2 $^{*}$ \\ ${ }^{1}$ Undergraduate Student of Faculty of Medicine, Public Health and Nursing, Universitas Gadjah Mada, Yogyakarta, \\ Indonesia \\ ${ }^{2}$ Department of Microbiology, Faculty of Medicine, Public Health and Nursing, Universitas Gadjah Mada, Yogyakar- \\ ta, Indonesia
}

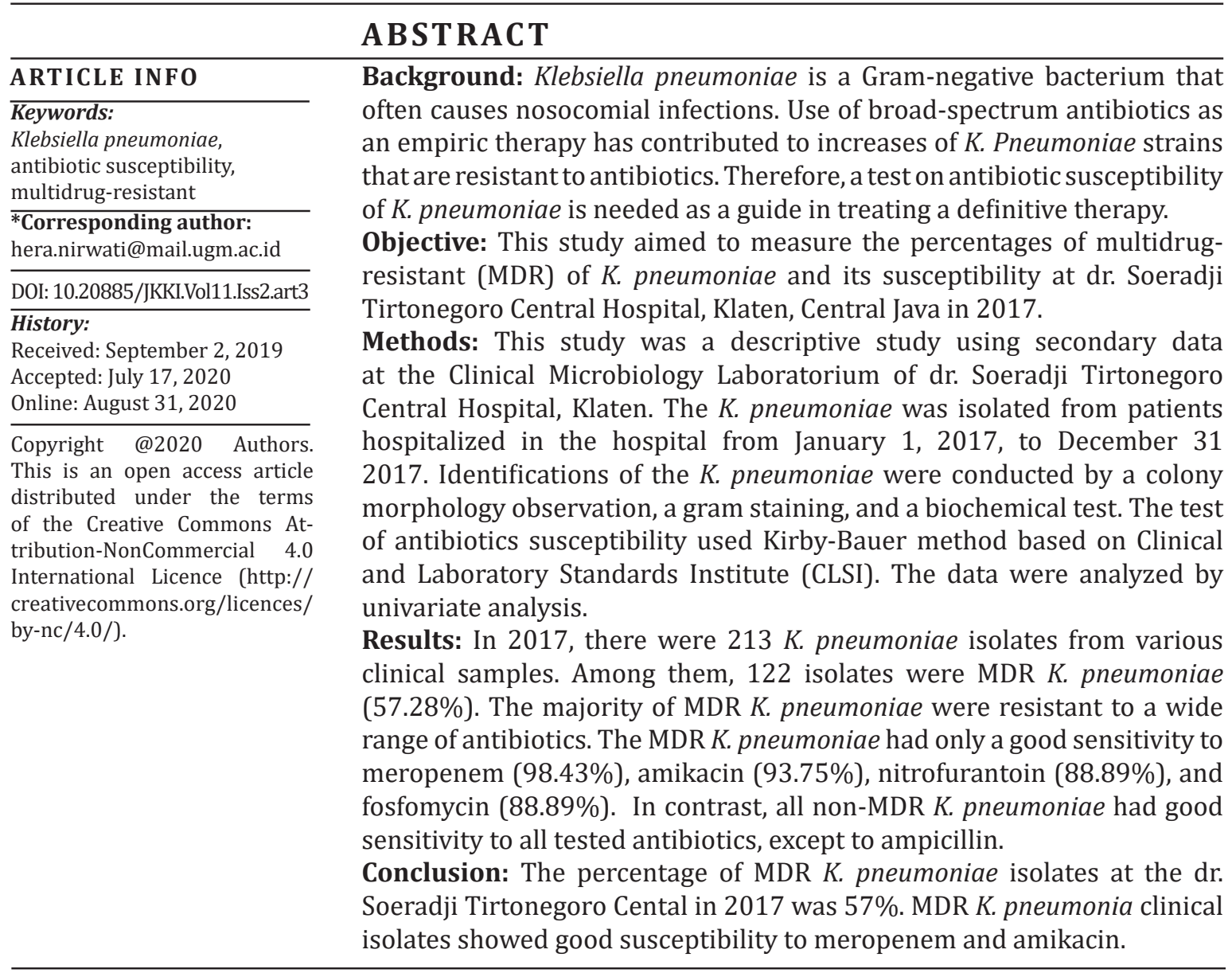

Latar Belakang: Klebsiella pneumoniae merupakan bakteri Gram negatif yang sering menyebabkan infeksi nosokomial. Penggunaan antibiotik spektrum luas sebagai terapi empirik menyebabkan meningkatnya strain $K$. pneumoniae yang resisten antibiotika. Oleh karena itu, diperlukan uji kepekaan terhadap antibiotik sebagai dasar pemberian terapi definitif dalam penanganan infeksi.

Tujuan: Untuk mengetahui persentase multidrug-resistant (MDR) K. pneumoniae dan pola kepekaannya terhadap berbagai antibiotika di RSUP dr. Soeradji Tirtonegoro, Klaten tahun 2017. 
Metode: Penelitian ini merupakan penelitian deskriptif analitik menggunakan data sekunder di Laboratorium Mikrobiologi RSUP dr. Soeradji Tirtonegoro tahun 2017. K. pneumoniae diisolasi dari sampel pasien yang mondok di RSUP Soeradji Tirtonegoro antara 1 Januari - 31 Desember 2017. Identifikasi K. pneumoniae dilakukan dengan pengamatan morfologi koloni, pengecatan Gram dan uji biokimiawi. Uji kepekaan terhadap antibiotika dilakukan dengan metode Kirby Bauer berdasakan CLSI. Data dianalisis dengan univariat. Hasil: Selama penelitian didapatkan 213 isolat K. pneumoniae dengan 122 isolat diantaranya adalah MDR K. pneumoniae (57.28\%). Sebagian besar MDR K. pneumoniae telah resisten terhadap antibiotik yang diujikan. MDR K. pneumoniae hanya mempunyai sensitivitas yang tinggi terhadap meropenem (98.43\%), amikacin (93.75\%), nitrofurantoin (88.89\%), dan fosfomisin (88.89\%). Sebaliknya, semua isolat K.pneumoniae yang bukan MDR, masih mempunyai sensitivitas yang baik terhadap semua antibiotika yang diujikan, kecuali terhadap ampicillin.

Kesimpulan: Presentase infeksi oleh MDR K. pneumoniae di RSUP dr. Soeradji Tirtonegoro, Klaten tahun 2017 adalah 57.28\%. MDR K. pneumoniae menunjukkan kepekaan yang baik terhadap meropenem dan amikasin

\section{INTRODUCTION}

Klebsiella pneumoniae is a Gram-negative and encapsulated bacterium that resides in mucosal surfaces of mammals and the environment such as soil, vegetation, and water. In humans, $K$. pneumoniae typically colonize the oropharynx and the gastrointestinal tract. It is also known as the most common cause of health-careassociated infection (HAIs) in the world. This bacterium can cause urinary tract infections, hospital-acquired pneumonia, ventilatorassociated pneumonia, surgical wound infection, bacteraemia, and septicemia. ${ }^{1}$ Children and patients with an immunocompromised immune system, such as patients in ICU, patients with malignancy, patients with HIV, patients with chemotherapy, or patients with diabetes, are more susceptible to a K. pneumoniae infection. ${ }^{2}$

Some studies reported increasing cases of HAIs caused by K. Pneumoniae.,4 Chung and collegues, who conducted a prospective surveillance study in 73 hospitals in 10 countries from 2008-2009, reported that the $K$. pneumoniae was one of the most frequent isolates from adults with hospital-acquired pneumonia (HAP) or ventilator-associated pneumonia (VAP) in Asian countries. ${ }^{3}$

World Health Organization (WHO) has defined as a threat to global health because of increasing numbers of resistant strains. ${ }^{5}$ Production of extended-spectrum betalactamases and other mechanisms of antibiotic resistance are favoured by a constant horizontal transfer of antimicrobial-resistant genes through mobile elements such as plasmids and transposons, which are essential factors for the $K$. pneumoniae to survive in hospital environments. The development of resistant bacteria has been increased due to frequent uses of broad-spectrum antibiotics for hospitalized patients, especially in ICU departments. ${ }^{6}$ High incidences of $K$. pneumoniae resistance can cause a limited choice of antibiotics for infection treatments leading to increased morbidity, mortality and hospital costs. ${ }^{5}$

Prevalence of $K$. pneumoniae infection was $13 \%$ in the United States of America, 5\% in Pakistan, $64.2 \%$ in Nigeria, 33.9\% in India, 17.4\% in Denmark, and 14.1\% in Singapore. ${ }^{7}$ In Indonesia, an infection of ESBL-producing K. pneumoniae was 35.35\% found in 297 inpatient isolates from January to April 2005 at dr. Soetomo Hospital, Surabaya. ${ }^{8}$ Prevalence of ESBL-producing K. pneumoniae became 23\% in January-June 2010, 50.28\% in JanuaryNovember 2011, 58\% in July-December 2012, and 38.5\% in October 2014-May 2015 at the dr. Soetomo Hospital. ${ }^{9,10}$ At Kariadi Hospital Semarang, ESBL-producing Enterobacteriaceae was $37.64 \%$ from 85 isolates. Meanwhile, at Saiful Anwar Hospital, Malang, a number of Enterobacteriaceae found was 52\% among 75 isolates. $^{11}$

Most of $K$. pneumoniae was reported to be resistant to various antibiotics like ampicillin, cefazolin, and cefuroxime that was the least effective for K. pneumonia; meanwhile, amikacin, 
piperacillin-tazobactam, and meropenem had the most favourable profile. ${ }^{12}$ This report of $K$. pneumonia is supported by a study conducted by Madahiah founding that K. pneumoniae isolates were $100 \%$ resistant to ampicillin and $100 \%$ sensitive to amikacin. ${ }^{13}$ Then ciprofloxacin and amoxicillin-clavulanic acid indicated 38.75\% and $36.69 \%$ resistance, respectively. Results of the study are similar to a study of Cepas et al. reporting that $40 \%$ of K. pneumoniae strains were resistant to ciprofloxacin and amoxicillinclavulanic acid. ${ }^{14}$

The antibiotic susceptibility pattern of $K$. pneumoniae can vary from time to time in a particular location. Thus, it is significant to conduct monitoring on multidrug-resistance (MDR) organisms as an antibiotic susceptibility test is needed by clinicians to determine an effective definitive therapy in managing infections. ${ }^{15}$ Therefore this study was conducted to determine incidences of MDR K. pneumoniae infections and its susceptibility pattern to various antibiotics at $\mathrm{dr}$. Soeradji Tirtonegoro Central Hospital, Klaten.

\section{METHODS}

A cross-sectional study was conducted using secondary data in the Clinical Microbiology Laboratory of dr. Soeradji Tirtonegoro Central Hospital, Klaten. Subjects of this study were K. pneumoniae isolates obtained from various clinical samples of hospitalized patients at the hospital, from January-December 2017. Identification of K. pneumoniae was organized by culturing on Mc Conkey agar, microscopic examinations with Gram staining and biochemical test using Microbact ${ }^{\mathrm{TM}}$ GNB 24E (Oxoid, UK).

Antibiotic susceptibility tests were conducted by the Kirby Bauer method based on the Clinical and Laboratory Standards Institute (CLSI). The used antibiotics included ampicillin $(10 \mu \mathrm{g})$, gentamicin $(10 \mu \mathrm{g})$, ceftriaxone $(30 \mu \mathrm{g})$, trimethoprim-sulfamethoxazole $(25 \mu \mathrm{g})$, cefuroxime $(30 \mu \mathrm{g})$, ciprofloxacin $(5 \mu \mathrm{g})$, cephazolin $(30 \mu \mathrm{g})$, nitrofurantoin
$(100 \mu \mathrm{g})$, amikacin $(30 \mu \mathrm{g})$, meropenem $(10 \mu \mathrm{g})$, levofloxacin $(5 \mu \mathrm{g})$, tobramycin $(10 \mu \mathrm{g})$, and piperacillin-tazobactam $(100 / 10 \mu g)$. The antibiotics were tested according to agreements of the Indonesian Society for Clinical Microbiologist (PAMKI) 2015 based on CLSI references. ${ }^{16}$ The K. pneumoniae was classified as a multidrug-resistant (MDR) K. pneumoniae if the isolates were resistant to three or more different classes of antimicrobials. ${ }^{17}$

This study was approved by the Ethical Committee, Faculty of Medicine, Public Health and Nursing, Universitas Gadjah Mada, Yogyakarta, Indonesia by a number: KE/ FK/0862/EC/2017.

\section{RESULTS}

A During the period of January-December 2017, there were $213 \mathrm{~K}$. pneumoniae isolates from 1,105 (19.28\%) total clinical bacterial isolates at dr. Soeradji Tirtonegoro Central Hospital. The K. pneumoniae isolates were obtained mostly from male patients (54.46\%). Based on age, the isolates mostly were from patients by $18-64$ years old (47.89\%). Most of the isolates were obtained from Melati Ward $(20.66 \%)$ and intensive care unit (ICU) (19.72\%). In addition, they were mostly obtained from respiratory specimens (61.97\%) that consisted of sputum, bronchial washing, tracheal aspirate, and bronchoalveolar lavage fluid (Table 1).

During the period of study, there were 122 MDR K. pneumoniae isolates (57.28\%). The $K$. pneumoniae was classified as an MDR $K$. pneumoniae if the isolates were resistant to three or more different classes of antimicrobials. ${ }^{17}$

Most of MDR K. pneumoniae were resistant to a wide range of antibiotics. Antibiotic sensitivity could be called good if it had $\geq 80 \%$ sensitivity. ${ }^{18}$ Then it had only a good sensitivity to meropenem (98.43\%), amikacin (93.75\%), nitrofurantoin (88.89\%), and fosfomycin (88.89\%) (Table 2). In contrast, all non-MDR K. pneumoniae had good sensitivity to all tested antibiotics, except to Ampicillin. 
Table 1. Clinical characteristics of patients with $K$. pneumoniae isolates

\begin{tabular}{|c|c|c|c|}
\hline \multirow{2}{*}{\multicolumn{2}{|c|}{ Characteristics }} & \multicolumn{2}{|c|}{ Total } \\
\hline & & \multirow{2}{*}{$\frac{\mathbf{n}}{116}$} & \multirow{2}{*}{$\begin{array}{c}\text { \% } \\
54.46\end{array}$} \\
\hline Sex & Male & & \\
\hline & Female & 86 & 40.38 \\
\hline & Unknown & 11 & 5.16 \\
\hline & Total & 213 & 100 \\
\hline \multirow[t]{5}{*}{ Age (year) } & $<18$ & 42 & 19.72 \\
\hline & $18-64$ & 102 & 47.89 \\
\hline & $\geq 65$ & 60 & 28.17 \\
\hline & Unknown & 9 & 4.23 \\
\hline & Total & 213 & 100 \\
\hline \multirow[t]{17}{*}{ Sampling Location } & Melati ward & 44 & 20.66 \\
\hline & ICU & 42 & 19.72 \\
\hline & Dahlia ward & 25 & 11.74 \\
\hline & Edelweis ward & 25 & 11.74 \\
\hline & PICU & 15 & 7.04 \\
\hline & HCU & 10 & 4.69 \\
\hline & Menur ward & 10 & 4.69 \\
\hline & Outpatient & 10 & 4.69 \\
\hline & Perinatology ward & 7 & 3.29 \\
\hline & Mawar ward & 5 & 2.35 \\
\hline & Teratai ward & 5 & 2.35 \\
\hline & Kenanga ward & 4 & 1.88 \\
\hline & NICU & 3 & 1.41 \\
\hline & Aster ward & 2 & 0.94 \\
\hline & ICCU & 2 & 0.94 \\
\hline & Unknown & 4 & 1.88 \\
\hline & Total & 213 & 100 \\
\hline \multirow[t]{5}{*}{ Clinical Specimen } & Respiratory & 132 & 61.97 \\
\hline & Wound & 48 & 22.54 \\
\hline & Blood & 20 & 9.39 \\
\hline & Urine & 13 & 6.10 \\
\hline & Total & 213 & 100 \\
\hline
\end{tabular}

In this study, the author used the CLSI M100-S25 document as a reference method for antibiotic susceptibility test based on the Indonesian Association of Clinical
Microbiologists in terms of specimen origins, which differentiate panels of antibiotics tested to each specimen based on its origins. Since the authors included various specimen sources, 
Virawan, et al. Multidrugresistant Klebsiella pneumo...

Table 2. Antibiotic susceptibility patterns of MDR-K. pneumoniae and non-MDR-K. pneumoniae isolates

\begin{tabular}{|c|c|c|c|c|c|c|c|c|c|c|}
\hline \multirow{3}{*}{ No } & \multirow{3}{*}{ Antibiotics } & \multirow{3}{*}{$\begin{array}{c}\text { Number } \\
\text { tested }\end{array}$} & \multicolumn{4}{|c|}{ MDR } & \multicolumn{4}{|c|}{ Non-MDR } \\
\hline & & & \multicolumn{2}{|c|}{ Sensitive } & \multicolumn{2}{|c|}{ Resistant } & \multicolumn{2}{|c|}{ Sensitive } & \multicolumn{2}{|c|}{ Resistant } \\
\hline & & & $\mathbf{n}$ & $\%$ & $\mathbf{n}$ & $\%$ & $\mathbf{n}$ & $\%$ & $\mathbf{n}$ & $\%$ \\
\hline 1 & Amikacin & 217 & 120 & 93.75 & 8 & 6.25 & 89 & 100.00 & 0 & 0.00 \\
\hline 2 & Amoxicillin & 203 & 29 & 25.89 & 83 & 74.11 & 90 & 98.90 & 1 & 1.10 \\
\hline 3 & Ampicillin & 194 & 2 & 1.75 & 112 & 98.25 & 2 & 2.50 & 78 & 97.50 \\
\hline 4 & Gentamicin & 163 & 40 & 43.48 & 52 & 56.52 & 70 & 98.59 & 1 & 1.41 \\
\hline 5 & Meropenem & 220 & 125 & 98.43 & 2 & 1.57 & 93 & 100.00 & 0 & 0.00 \\
\hline 6 & Levofloxacin & 227 & 77 & 59.23 & 53 & 40.77 & 97 & 100.00 & 0 & 0.00 \\
\hline 7 & Ceftriaxone & 186 & 17 & 15.74 & 91 & 84.26 & 78 & 100.00 & 0 & 0.00 \\
\hline 8 & $\begin{array}{l}\text { Trimethoprim } \\
\text { sulfamethoxazole }\end{array}$ & 203 & 22 & 20 & 88 & 80.00 & 87 & 93.55 & 6 & 6.45 \\
\hline 9 & Cefuroxime & 221 & 14 & 11.02 & 113 & 88.98 & 93 & 98.94 & 1 & 1.06 \\
\hline 10 & Ciprofloxacin & 99 & 21 & 35.99 & 38 & 64.01 & 37 & 92.50 & 3 & 7.50 \\
\hline 11 & Tobramycin & 227 & 37 & 28.46 & 93 & 71.54 & 94 & 96.91 & 3 & 3.09 \\
\hline 12 & $\begin{array}{l}\text { Piperacilin- } \\
\text { Tazobactam }\end{array}$ & 154 & 65 & 75.81 & 21 & 24.19 & 68 & 100.00 & 0 & 0.00 \\
\hline 13 & Cefazoline & 171 & 5 & 5.05 & 94 & 94.95 & 68 & 94.44 & 4 & 5.56 \\
\hline 14 & Nitrofurantoin & 12 & 8 & 88.89 & 88.89 & 88.89 & 3 & 100.00 & 0 & 0.00 \\
\hline 15 & Fosfomycin & 12 & 8 & 88.89 & 88.89 & 88.89 & 3 & 100.00 & 0 & 0.00 \\
\hline
\end{tabular}

a number of antibiotics tested to each isolate was different, depending on its specimen origin (Table 3, Table 4). ${ }^{16}$

The MDR K. pneumoniae isolated from respiratory specimens only had good sensitivity to meropenem (98.63\%) and amikacin (98.63\%). For MDR K. pneumoniae isolated from wound specimens, sensitivity to meropenem, amikacin and piperacillin-tazobactam were good with $100 \%, 90.48 \%$, and $80 \%$ respectively. All non-MDR K. pneumoniae isolated from respiratory and wound specimens had good sensitivity to all tested antibiotics, except to ampicillin (Table 3).

MDR K. pneumoniae isolated from blood specimens had the highest sensitivity to meropenem (100\%), followed by amikacin (93.75\%). All of non-MDR K. pneumoniae isolates obtained from blood were sensitive to amikacin, gentamicin, meropenem, levofloxacin, ceftriaxone, tobramycin, and piperacillintazobactam. The sensitivity of non-MDR $K$. pneumoniae isolates obtained from blood to ciprofloxacin, cefuroxime, and ampicillin was $75 \%, 75 \%$, and $0 \%$, respectively (Table 4 )

Resistance rates of MDR $K$. pneumoniae isolated from urine specimens to meropenem, amikacin, piperacillin-tazobactam, nitrofurantoin, and fosfomycin were $100 \%$; $100 \% ; 100 \%$; $88,89 \%$; and $88,89 \%$ respectively. In contrast, all non-MDR K. pneumoniae isolated from urine specimens had good sensitivity to all tested antibiotics, except to ampicillin (Table 4). 
Table 3A. Antibiotic susceptibility patterns of MDR K. pneumoniae and non-MDR K. pneumoniae isolated from respiratory specimens

\begin{tabular}{|c|c|c|c|c|c|c|c|c|c|c|}
\hline \multirow{4}{*}{ No } & \multirow{4}{*}{ Antibiotics } & \multirow{4}{*}{$\begin{array}{c}\text { Number } \\
\text { tested }\end{array}$} & \multicolumn{8}{|c|}{ Respiratory } \\
\hline & & & \multicolumn{4}{|c|}{ MDR } & \multicolumn{4}{|c|}{ Non-MDR } \\
\hline & & & \multicolumn{2}{|c|}{ Sensitive } & \multicolumn{2}{|c|}{ Resistant } & \multicolumn{2}{|c|}{ Sensitive } & \multicolumn{2}{|c|}{ Resistant } \\
\hline & & & $n$ & $\%$ & $n$ & $\%$ & $n$ & $\%$ & $n$ & $\%$ \\
\hline 1 & Amikacin & 126 & 70 & 94.59 & 4 & 5.41 & 52 & 100.00 & 0 & 0.00 \\
\hline 2 & Amoxicillin & 130 & 17 & 22.97 & 57 & 77.03 & 55 & 98.21 & 1 & 1.79 \\
\hline 3 & Ampicillin & 113 & 1 & 1.52 & 65 & 98.48 & 1 & 2.13 & 46 & 97.87 \\
\hline 4 & Gentamicin & 96 & 23 & 40.35 & 34 & 59.65 & 39 & 100.00 & 0 & 0.00 \\
\hline 5 & Meropenem & 126 & 72 & 98.63 & 1 & 1.37 & 53 & 100.00 & 0 & 0.00 \\
\hline 6 & Levofloxacin & 130 & 51 & 68.92 & 23 & 31.08 & 56 & 100.00 & 0 & 0.00 \\
\hline 7 & Ceftriaxone & 106 & 8 & 13.11 & 53 & 86.89 & 45 & 100.00 & 0 & 0.00 \\
\hline 8 & $\begin{array}{l}\text { Trimethoprim } \\
\text { sulfamethoxazole }\end{array}$ & 126 & 13 & 18.57 & 57 & 81.43 & 52 & 92.86 & 4 & 7.14 \\
\hline 9 & Cefuroxime & 125 & 9 & 12.68 & 62 & 87.32 & 53 & 98.15 & 1 & 1.85 \\
\hline 10 & Tobramycin & 130 & 24 & 32.43 & 50 & 67.57 & 55 & 98.21 & 1 & 1.79 \\
\hline 11 & Tazobactam & 91 & 40 & 72.73 & 15 & 27.27 & 36 & 100.00 & 0 & 0.00 \\
\hline 12 & Cefazolin & 113 & 3 & 4.48 & 64 & 95.52 & 43 & 93.48 & 3 & 6.52 \\
\hline 13 & Ciprofloxacin & - & - & - & & & - & - & 0 & 0.00 \\
\hline
\end{tabular}

Table 3B. Antibiotic susceptibility patterns of MDR K. pneumoniae and non-MDR K. pneumoniae isolated from wound specimens

\begin{tabular}{|c|c|c|c|c|c|c|c|c|c|c|}
\hline \multirow{4}{*}{ No } & \multirow{4}{*}{ Antibiotics } & \multirow{4}{*}{$\begin{array}{l}\text { Number } \\
\text { tested }\end{array}$} & \multicolumn{8}{|c|}{ Wound } \\
\hline & & & \multicolumn{4}{|c|}{ MDR } & \multicolumn{4}{|c|}{ Non-MDR } \\
\hline & & & \multicolumn{2}{|c|}{ Sensitive } & \multicolumn{2}{|c|}{ Resistant } & \multicolumn{2}{|c|}{ Sensitive } & \multicolumn{2}{|c|}{ Resistant } \\
\hline & & & n & $\%$ & $\mathbf{n}$ & $\%$ & n & $\%$ & n & $\%$ \\
\hline 1 & Amikacin & 42 & 19 & 90.48 & 2 & 9.52 & 21 & 100.00 & 0 & 0.00 \\
\hline 2 & Amoxicillin & 43 & 9 & 42.86 & 12 & 57.14 & 22 & 100.00 & 0 & 0.00 \\
\hline 3 & Ampicillin & 40 & 1 & 5.00 & 19 & 95.00 & 0 & 0.00 & 20 & 100.00 \\
\hline 4 & Gentamicin & 34 & 6 & 40.00 & 9 & 60.00 & 19 & 100.00 & 0 & 0.00 \\
\hline 5 & Meropenem & 44 & 22 & 100.00 & 0 & 0.00 & 22 & 100.00 & 0 & 0.00 \\
\hline 6 & Levofloxacin & 45 & 8 & 36.36 & 14 & 63.64 & 23 & 100.00 & 0 & 0.00 \\
\hline 7 & Ceftriaxone & 39 & 4 & 21.05 & 15 & 78.95 & 20 & 100.00 & 0 & 0.00 \\
\hline 8 & $\begin{array}{l}\text { Trimethoprim } \\
\text { sulfamethoxazole }\end{array}$ & 45 & 4 & 18.18 & 18 & 81.82 & 22 & 95.65 & 1 & 4.35 \\
\hline 9 & Cefuroxime & 45 & 1 & 4.55 & 21 & 95.45 & 23 & 100.00 & 0 & 0.00 \\
\hline 10 & Tobramycin & 46 & 7 & 30.43 & 16 & 69.57 & 22 & 95.65 & 1 & 4.35 \\
\hline 11 & Tazobactam & 34 & 12 & 80.00 & 3 & 20.00 & 19 & 100.00 & 0 & 0.00 \\
\hline 12 & Cefazolin & 38 & 2 & 10.00 & 18 & 90.00 & 18 & 100.00 & 0 & 0.00 \\
\hline 13 & Ciprofloxacin & 46 & 5 & 21.74 & 18 & 78.26 & 23 & 100.00 & 0 & 0.00 \\
\hline
\end{tabular}




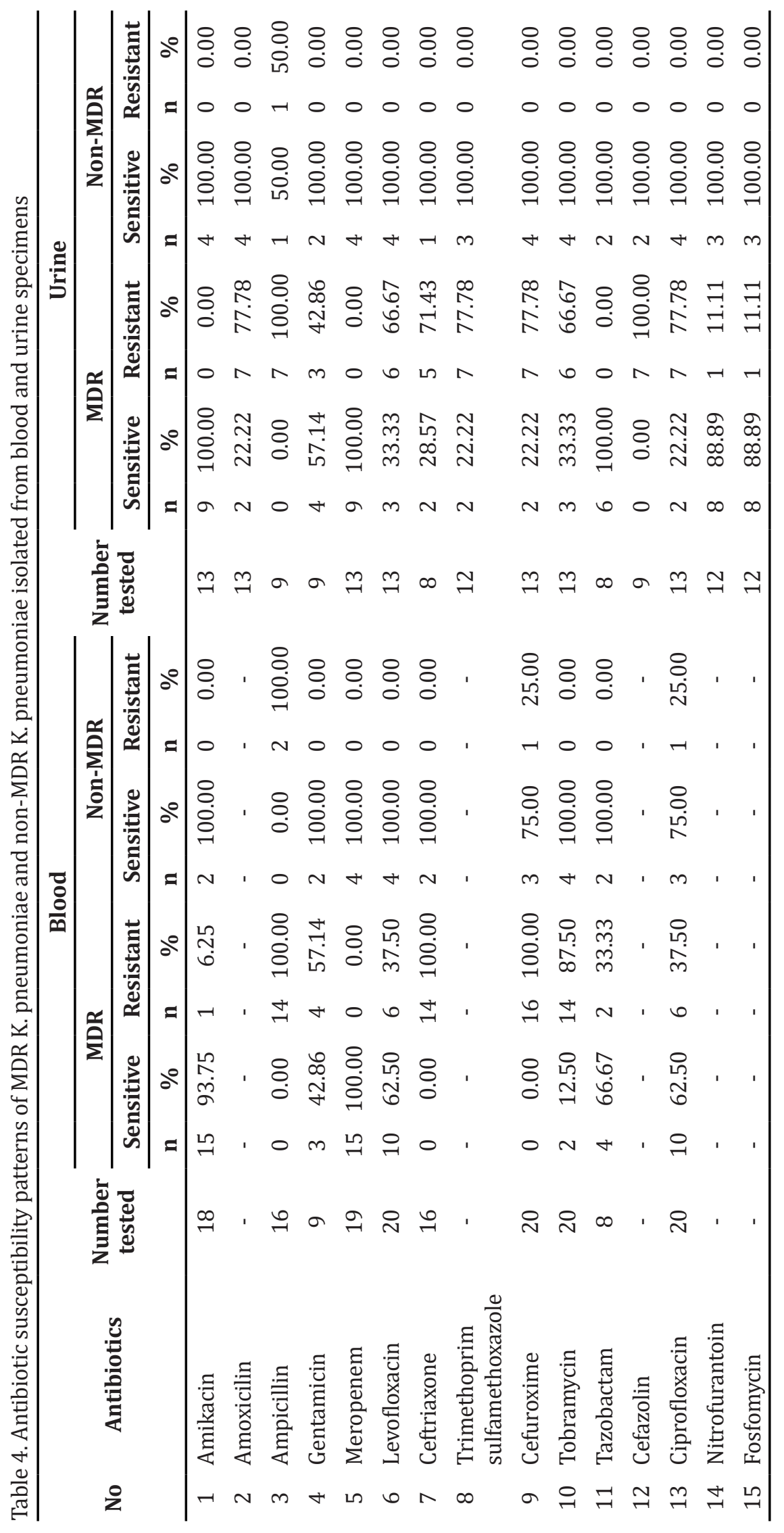




\section{DISCUSSION}

This study showed high incidences of MDR $K$. pneumoniae infections at dr. Soeradji Tirtonegoro Central Hospital, Klaten, in 2017. This result was in line with several studies. Setyati and Murni reported that K. pneumoniae was common causative agents in patients admitted to PICU of dr. Sardjito Central Hospital. ${ }^{19}$ Another study, Manikandan and Amsath also reported about $K$. pneumoniae infections in Tamil Nadu, India. ${ }^{20}$ The high incidences of K. pneumoniae infections could correlate with a decreasing immune system function. Patients with diabetes or malignancy more susceptible to get K. pneumoniae infection. Use of an invasive medical instrument such as a catheter or an endotracheal tube for a long time contribute to incidences of $K$. pneumoniae infections as well. ${ }^{21}$

K. pneumoniae could colonize nasopharynx and gastrointestinal tracts. The bacteria could also be found on the skin as transient bacteria. Before infections happened, $80 \%$ of patients infected by ESBL-producing K. pneumoniae had the same bacteria colony in their gastrointestinal tracts. ${ }^{22}$ Nasopharynx colonization also could be related to alcohol consumption. Alcohol could change mucosal immunity due to normal flora changing in mucosal surfaces. ${ }^{23} \mathrm{High}$ Klebsiella colonization could be related to a broad spectrum and antibiotic combination exposures. ${ }^{24}$ Risk factors of $K$. pneumoniae infections could include uses of a catheter, prior colonization, severe illness, length of inpatient care, invasive treatment, length of antibiotic use, poor personal and environmental hygiene, and poor immunity. 7,25

Based on the sex characteristics, $K$. pneumoniae isolates were mostly obtained from male patients. This result was concordant with other studies. Even though showing different results, most of the studies reported that $K$. pneumoniae isolates were obtained mostly from male patients. However, there was no statistical significance between males and female. ${ }^{26,27}$

K. pneumoniae in this study were mostly obtained from adult patients by age between 1864 years of age. This result was in concordance with a study conducted by Osagie and collegues, who collected samples from 5 primary health cares in Nigeria. ${ }^{27}$ The adult group productive ages as they will be exposed directly to their surroundings. ${ }^{27}$ Increasing age also could lead to a higher risk of $K$. pneumoniae infection due to increasing incidences of comorbid illness.

In this study, K. pneumoniae mostly isolated from Melati Ward which was for internal medicine patients provided five beds in one room. Because of its density, it could be spread easily from one patient to the others. The high incidences of $K$. pneumoniae infections also happened in the ICU department. This might be caused by exposures toward invasive procedures, such as intubation, mechanical ventilation, urine catheterization, artery catheterization, or central vein catheterization. Duration of care in the ICU would determine the incidence of infection as well..$^{28,29}$

Based on the source of the specimens, $K$. pneumoniae isolates were mostly found in the respiratory specimen. This was because $K$. pneumoniae was primary bacteria that usually could cause infection in the respiratory tracts, which could be manifested as pneumonia, sinusitis, or even otitis. ${ }^{30}$ Other studies supported these findings, as well. ${ }^{30,31}$ Some of the $K$. pneumoniae isolates were obtained from the wound specimens. Infection in a wound usually was obtained when the patients received care in a hospital after trauma, burn injury, or surgical procedure. ${ }^{32}$ The infection of the wound might cause sepsis, longer hospital stay, and increasing healthcare cost, and it also might affect the morbidity and mortality of an individual. ${ }^{33}$ Other studies also showed similar results as findings in this study. ${ }^{34,35}$

Based on this study, generally, amikacin and meropenem were highly effective against MDR K. pneumoniae infections. In contrast, MDR K. pneumoniae was found to be resistant against ampicillin, gentamicin, ceftriaxone, trimethoprim-sulfamethoxazole, cefuroxime, ciprofloxacin, cefazolin, levofloxacin, and tobramycin.

Another study held in dr. Kariadi Central 
Hospital Semarang also showed high sensitivity to meropenem. ${ }^{36}$ Meropenem usually could be the third antibiotic used in the management of $K$. pneumoniae infection, so the exposure of K. pneumoniae toward this antibiotic could be infrequent. This might cause susceptibility rates of $K$ pneumoniae toward meropenem to be still high. ${ }^{37}$

In this study, the authors found a high number of MDR K. pneumoniae isolates (57.28\%). ${ }^{38} \mathrm{~A}$ study conducted in India also showed a high number of MDR K. pneumoniae isolates. A study conducted in Iran showed that $46.6 \%$ of K. pneumoniae were MDR, with a high rate of resistance toward ampicillin, cephalosporin $3^{\text {rd }}$ generation, and also aminoglycoside (especially gentamycin). ${ }^{39}$ The high number of MDR $K$. pneumoniae isolates might be affected by history and duration of inpatient care in the hospital, history of antibiotic use, and also a history of health care obtained in the wards. ${ }^{39}$ The use of the invasive device in the hospital for a long term was also a significant risk factor. ${ }^{40}$

Managing infections caused by MDR $K$. pneumoniae could become a challenge for clinicians. A combination of antibiotics using colistin is a drug of choice, which can be colistinmeropenem, colistin-meropenem-tigecycline, colistin-tigecycline, colistin-gentamycin, and colistin-vancomycin. Nevertheless, these combinations of antibiotics may have a certain effect, such as nephrotoxicity. ${ }^{41}$ A study showed that therapy using a combination of antibiotics could prevent the emergence of new resistant strains during the therapy process, so its use in the management of MDR K. pneumoniae was highly recommended. ${ }^{42}$

In the dr. Soeradji Tirtonegoro Central Hospital, antibiotic usage was controlled by a team called Tim Program Pengendalian Resistensi Antibiotik (PPRA), a team to manage antibiotic resistance. In general, antibiotic usage should be based on the clinical microbiology result. Collecting clinical samples before antibiotic administration was a significant point. The result of the antibiotic sensitivity test would be analyzed to make an antibiogram. The antibiogram could be used as a guide for empirical therapy and a monitor for antimicrobial-resistant trends in the hospital. In addition, the appropriateness of prophylaxis antibiotics and de-escalation of definitive antibiotics have not yet audited, which might give impact to the presence of multiresistant phenotypes.

Based on this study, it could be seen that MDR K. pneumoniae isolates in the dr. Soeradji Tirtonegoro Central Hospital was high. Therefore, it is very important to conduct control of hospital infection and antibiotic stewardship effectively. A hospital needs to have an antibiotic guidance or stewardship program based on the most accurate microbiological data. In conjunction with the guidance, a continuous effort in hospital pathogen surveillance, infection control, and clinical audits should be conducted to fight against rapid development of antibiotic-resistant pathogens.

This study had limitations due to a limited number of $K$. pneumoniae isolated from blood and urine specimens. The result of the antibiotic sensitivity test could be analyzed to make an antibiogram that could be used for empirical therapy and a monitor for antimicrobial resistance trends. To do this, at least 30 clinically isolates should be collected for their analysis.

\section{CONCLUSION}

The prevalence of MDR $K$. pneumoniae isolates in RSUP dr. Soeradji Tirtonegoro, Klaten was high. Most of them were resistant to various antibiotics. MDR K pneumoniae clinical isolates showed good susceptibility against meropenem and amikacin.

\section{CONFLICT OF INTEREST}

There was no conflict of interest.

\section{ACKNOWLEDGEMENT}

This study was financially supported by the Dana Masyarakat Grant (2017), Faculty of Medicine, Public Health and Nursing Universitas Gadjah Mada, Yogyakarta. The authors would thank dr. Hesty Lusinta Sp.MK, Margono, Erna Yulis Setiawati, and Retno Wulandari for their 
technical assistance. We also thank dr. Nintya Assyarifa and dr. Syahra Kurnia Putri for critical editing of the manuscript.

\section{REFERENCES}

1. Tian L, Tan R, Chen Y, Sun J, Liu J, Qu H, et al. Epidemiology of Klebsiella pneumoniae bloodstream infections in a teaching hospital: Factors related to the carbapenem resistance and patient mortality. Antimicrobial Resistance and Infection Control. 2016;5(1).

2. Apondi OE, Oduor OC, Gye BK, Kipkoech MK. High prevalence of multidrug resistant Klebsiella Pneumoniae in a tertiary teaching hospital in Western Kenya. African Journal of Infectious Diseases. 2016;10(2):8995.

3. Chung DR, Song JH, Kim SH, Thamlikitkul V, Huang SG, Wang H, et al. High prevalence of multidrug-resistant nonfermenters in hospital-acquired pneumonia in Asia. American Journal of Respiratory and Critical Care Medicine. 2011;184(12):1409-17.

4. Murni IK, Duke T, Daley AJ, Kinney S, Soenarto Y. Antibiotic resistance and mortality in children with nosocomial bloodstream infection in a teaching hospital in indonesia. Southeast Asian Journal of Tropical Medicine and Public Health. 2016;47(5):983-93.

5. Kidd TJ, Mills G, Sá-Pessoa J, Dumigan A, Frank CG, Insua JL, et al. A Klebsiella pneumoniae antibiotic resistance mechanism that subdues host defences and promotes virulence. EMBO Molecular Medicine. 2017;9(4):430-47.

6. Karam G, Chastre J, Wilcox MH, Vincent JL. Antibiotic strategies in the era of multidrug resistance. Critical Care. 2016;20(1):1-9.

7. Alebachew Woldu M. Klebsiella pneumoniae and its growing concern in healthcare settings. Clinical and Experimental Pharmacology. 2016;6(1):1-7.

8. Kuntaman K, Mertaniasih NM, Hadi U. Multiresistance pattern of extended spectrum B -Lactamase (Esbl). Folia Medica Indonesiana. 2006;42(1):40-6.

9. Hadi U, Kuntaman K, Qiptiyah M, Paraton H. Problem of antibiotic use and antimicrobial resistance in Indonesia: Are we really making progress? Indonesian Journal of Tropical and Infectious Disease. 2013;4(4):5.

10. Fitri NN, Rusli M, Wahyunitisari RM. Antibiotic use is not a risk factor of infection by extended-spectrum Beta-Lactamase producing bacteria in dr. Soetomo Hospital Surabaya. Microbiology Indonesia. 2015;9(4):150-6.

11. Kuntaman K, Santoso S, Wahjono H, Mertaniasih NM, Lestari ES, Farida H, et al. The sensitivity pattern of extended spectrum Beta Lactamase-Producing bacteria against six antibiotics that routinely used in clinical setting. Journal of Indonesia Medical Association. 2011 December 1;61(12):482-6.

12. Sinanjung K. Proporsi Klebsiella Pneumoniae isolat klinik penghasil extended spectrum Beta Lactamase (ESBL) beserta pola kepekaannya terhadap antibiotika di RSUP dr Soeradji Tirtonegoro Klaten [Internet]. Universitas Gadjah Mada; 2019. http://etd.repository.ugm.ac.id/index. php? $\bmod =$ penelitian_detail $\&$ sub $=$ PenelitianDetail\&act=view\&typ=html\&buku id=170392\&is_local=1

13. Madahiah M, Noor S, Abdul S, Ali Abbas Q. Klebsiella pneumoniae urinary tract infections associated with long-term catherterizaton and spinal cord injuries. Jornal of Medical Sciences [Internet]. 2002;2(56):227-9.

14. Cepas V, López Y, Muñoz E, Rolo D, Ardanuy C, Martí S, et al. Relationship between biofilm formation and antimicrobial resistance in Gram-Negative bacteria. Microbial Drug Resistance. 2019;25(1):72-9.

15. Moremi N, Claus H, Mshana SE. Antimicrobial resistance pattern: A report of microbiological cultures at a tertiary hospital in Tanzania. BMC Infectious Diseases. 2016;16(1):1-7.

16. Franklin R. Cockerill, III M, Jean B. Patel, PhD D. M100-S25 performance standards for antimicrobial susceptibility testing; twenty-fifth informational supplement. Clinical and Laboratory Standards Institute. 2015;

17. Magiorakos AP, Srinivasan A, Carey RB, 
Carmeli Y, Falagas ME, Giske CG, et al. Multidrug-resistant, extensively drug-resistant and pandrug-resistant bacteria: An international expert proposal for interim standard definitions for acquired resistance. Clinical Microbiology and Infection. 2012;18(3):268-81.

18. Menkes RI. Permenkes RI No. 8 Tahun 2015 tentang program pengendalian resistensi antimikroba di rumah sakit. Hukor Depkes RI. 2015;

19. Setyati A, Murni IK. Pola kuman pasien pneumonia di instalasi rawat intensif anak (IRIA) RSUP Dr. Sardjito. Media Medika Indonesiana. 2012;46(3):195-200.

20. Manikandan C, Amsath A. From urine samples. International Journal of Current Microbiology and Applied Sciences. 2013;2(8):330-7.

21. Paczosa MK, Mecsas J. Klebsiella pneumoniae: Going on the offense with a strong defense. Microbiology and Molecular Biology Reviews. 2016;80(3):629-61.

22. Peña C, Pujol M, Ardanuy C, Ricart A, Pallares R, Liñares J, et al. Epidemiology and successful control of a large outbreak due to Klebsiella pneumoniae producing extended spectrum $\beta$-lactamases. Antimicrobial Agents and Chemotherapy. 1998;42(1):53-8.

23. Dao TT, Liebenthal D, Tran TK, Vu BNT, Nguyen DNT, Tran HKT, et al. Klebsiella pneumoniae oropharyngeal carriage in rural and urban Vietnam and the effect of alcohol consumption. Plos One. 2014;9(3).

24. Podschun R, Ullmann U. Klebsiella spp. as nosocomial pathogens: Epidemiology, taxonomy, typing methods, and pathogenicity factors. Clinical Microbiology Reviews. 1998.

25. Pitout JD, Laupland KB. Extended-spectrum $\beta$-lactamase-producing Enterobacteriaceae: An emerging public-health concern. The Lancet Infectious Diseases. 2008;8(3):159-66.

26. Akter J, Masudul Azad Chowdhury AM, Forkan M Al. Study on prevalence and antibiotic resistance pattern of Klebsiella isolated from clinical samples in South East Region of Bangladesh. American Journal of Drug Discovery and Development. 2014;4(1):739.

27. Osagie RN, Eyaufe A., Iserhienrhien O, Okodua M, Unuabonah F, Daibo O. Antibiotic susceptibility profile of Klebsiella pneumoniae isolated from sputum samples amongst hospitalized adults in parts of Edo State, South-South, Nigeria. Merit Research Journal of Medicine and Medical Sciences. 2017;5(8):378-83.

28. Dasgupta S, Das S, Chawan NS, Hazra A. Nosocomial infections in the intensive care unit: Incidence, risk factors, outcome and associated pathogens in a public tertiary teaching hospital of Eastern India. Indian Journal of Critical Care Medicine. 2015;19(1):14-20.

29. Tran GM, Ho-Le TP, Ha DT, Tran-Nguyen CH, Nguyen TSM, Pham TTN, et al. Patterns of antimicrobial resistance in intensive care unit patients: A study in Vietnam. BMC Infectious Diseases. 2017;17(1):1-7.

30. Rammaert B, Goyet S, Beauté J, Hem S, Te V, Try PL, et al. Klebsiella pneumoniae related community-acquired acute lower respiratory infections in Cambodia: Clinical characteristics and treatment. BMC Infectious Diseases. 2012;12(1):3.

31. Anggraini D, Hasanah U, Savira M, Andrini F, Irawan D, Prima R. Prevalence and Susceptibility Profile of ESBL-producing Enterobacteriaceae in Arifin Achmad General Hospital Pekanbaru. Jurnal Kedokteran Brawijaya. 2018;30(1):47-52.

32. Trojan R, Razdan L, Singh N. Antibiotic Susceptibility patterns of bacterial isolates from pus samples in a tertiary care hospital of Punjab, India. International Journal of Microbiology. 2016;2016 (January 2014).

33. Mahat P, Manandhar S, Baidya R. Bacteriological profile of wound infection and antibiotic susceptibility pattern of the isolates. Journal of Microbiology \& Experimentation. 2017;4(5):126-33.

34. Sarathbabu DR. Antibiotic susceptibility pattern of Klebsiella pneumoniae isolated from sputum, urine and pus samples. IOSR Journal of Pharmacy and Biological Scienc- 
es. 2012;1(2):4-9.

35. Ravichitra KN, Prakash PH, Subbarayudu S, Rao US. Isolation and antibiotic sensitivity of Klebsiella pneumoniae from pus, sputum and urine samples. International Journal of Current Microbiology and Applied Sciences. 2014;3(3):115-9.

36. Dairo MT. Pola kuman berdasarkan spesimen dan sensitivitas terhadap antibiotik pada penderita community-acquired pneumonia (CAP) di RSUP Dokter Kariadi Semarang. Universitas Diponegoro; 2014.

37. Kurniawan J. Artikel penelitian pola kepekaan bakteri penyebab pneumonia terhadap antibiotika di laboratorium mikrobiologi RSUP Dr . M . Djamil. Jurnal Kesehatan Andalas. 2011;4(2):562-6.

38. Shivannavar CT. Antibiotic susceptibility pattern of ES $\beta \mathrm{L}$ producing Klebsiella pneumoniae isolated from urine samples of pregnant women in Karnataka. Journal of Clinical and Diagnostic Research. 2014;8(10):8-11.

39. Erami M, Soltani B, Ardakani AT, Moravveji A, Moini AS, Rezaei MH, et al. Multidrug-resistant Escherichia coli and Klebsiella pneumoniae isolated from patients in Kashan, Iran. Jundishapur Journal of Microbiology. 2015;8(10).

40. Rath S, Padhy RN. Prevalence of two multidrug-resistant Klebsiella species in an Indian teaching hospital and adjoining community. Journal of Infection and Public Health. 2014;7(6):496-507.

41. Mascellino MT, Angelis M De, Oliva A. Multidrug resistant gram-negative bacteria: Antibiotic-resistance and new treatment strategies. Diagnostic Pathology: Open Access. 2017;02(02):10-3

42. Petrosillo N, Giannella M, Lewis R, Viale P. Treatment of carbapenem-resistant Klebsiella pneumoniae: The state of the art. Expert Review of Anti-Infective Therapy. 2013;11(2):159-77. 